https://doi.org/10.37208/tgn27312

\section{Clavigesta purdeyi (Lepidoptera: Tortricidae): a moth new to Scotland}

\author{
R.B. Weddle \\ 89 Novar Drive, Glasgow G12 9SS \\ E-mail: richard@canto.plus.com
}

On July 26th 2018 Alan Winthrop found a micro-moth which he provisionally identified as Clavigesta purdeyi (Durrant, 1911) in his greenhouse in Bishopbriggs, East Dunbartonshire, Scotland (Fig. 1). It had probably been attracted into the greenhouse by an ultraviolet light.

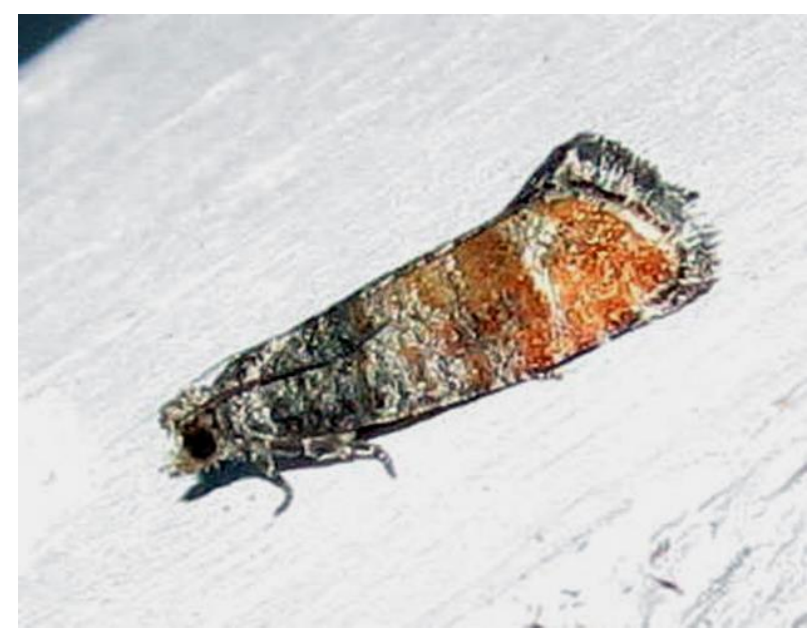

Fig. 1. Pine leaf-mining moth Clavigesta purdeyi, Bishopbriggs, East Dunbartonshire, Scotland; forewing length $6 \mathrm{~mm}$. (Photo: Alan Winthrop)

A photograph of the specimen was submitted to Dr Mark Young and Nigel Richards who jointly verified it on the grounds of flight time, size, and head colour compared with the similar Clavigesta posticana, C. turionella and C. logaea. On 12th August 2020, a second specimen occurred in a moth trap at Glasgow Botanic Gardens (pers. obs.). This was a female and was confirmed from the genitalia by Nigel Richards. The list of Scottish micro-moths maintained by Dr Young on behalf of Butterfly Conservation did not include this species, which is therefore an addition to the Scottish fauna.

C. purdeyi has been given the common name pine leaf-mining moth; the larva mines the needles of Scots pine (Pinus sylvestris), Corsican pine ( $P$. nigra subsp. laricio), lodgepole pine ( $P$. contorta) etc. and is "local" in coniferous woodland in northern England (Sterling et al., 2012). The same source mentions that it seemed to be expanding its range in England, and had been recorded for the first time in Ireland, so its arrival in Scotland is perhaps not unexpected. It is very likely to be present in Dumfries and Galloway and/or the Scottish Borders.

There is a mature stand of pines near to the Bishopbriggs location in Meadowburn, and several long-established mixed woodlands within $1 \mathrm{~km}$, such as Cadder Wilderness plantation, and the woodlands of Cawder House (now surrounding a golf course). Glasgow Botanic Gardens has a collection of various Pinus spp.

The sightings fall within the Watsonian Vice-county of Lanarkshire (VC77).

\section{REFERENCE}

Sterling, P., Parsons, M., \& Lewington, R. (2012). Field Guide to the Micromoths of Great Britain and Ireland. British Wildlife Publishing, Dorset. 